\title{
The Performance Evaluation of Teachers of Higher Public Education in East Timor: The Need for a New Model (The Evaluation of the Lecturing Performance in East Timor)
}

\author{
Abílio António Freitas Belo ${ }^{a^{*}}$ \\ a University of Minho, Portugal. \\ ${ }^{*}$ Corresponding author's email address:
}

\section{A R T I C L E I N F O}

Received: 29-02-2016

Accepted: 12-04-2016

Available online: 26-05-2016

Keywords:

East Timor;

Performance evaluation;

Professors;

Public higher education.

JEL Classification:

A2, C49, I2.

\begin{abstract}
A B S T R A C T
The evaluation of the lecturing performance in East Timor is a key part of the Timorese education system that declares, in accordance with the Law on Education (2008), that higher education is oriented towards the development of national human resources. Higher education institutions are therefore called upon to provide a wider public service and simultaneously more efficient and with better results. However, the evaluation of professors in the public higher education sphere follows the exact same procedures and criteria that are being applied to all public servants of Timorese administration. This article aims to argue there is a real need for the implementation in the higher education institutions of an assessment tool that meets the specific role and goals of public higher education institutions, thus filling a gap in the study of lecturer's performance evaluation in East Timor.
\end{abstract}

(C) 2016 The Authors. This is an open access article under the terms of the Creative Commons Attribution License 4.0, which allows use, distribution and reproduction in any medium, provided the original work is properly cited.

DOI: http://dx.doi.org/10.18533/rss.v1i5.31

\subsection{Introduction}

The rapid expansion of higher education in recent decades allowed host a large number of students in many countries (Altbach, 1998), but also created the need for administrative reform that would allow the implementation of a model more effective, efficient and economic management. Higher education institutions were thus called upon to provide a public service, not only longer, but also with greater administrative efficiency and deliver results (accountability) in response to the demands of different stakeholders (governments, companies, industry, workers organizations, students and the community in general) (Ka-ho, 2013).

At the same time, society today is demanding increasingly demonstrating the value of the work of higher education teachers also being increasingly recognized that universities require special attention to meet the specific needs of their human resources management in order to position themselves in order to define quality criteria and effectiveness of the service provided.

Therefore, we discuss the performance evaluation framed in the paradigm of the new human resources management in public administration, to argue that the current performance evaluation model applied to all civil servants in East Timor does not meet the requirements and specificities of Timoreses public higher education. For being too broad, the current evaluation system used to evaluate the performance of university 
teachers or lecturers does not contain the necessary adjustments to the objectives and challenges of higher education in the country. Therefore, this paper, theoretical and critical nature, intends to point out the foundation and the guiding principles for the design of a new model of evaluation of teaching performance, in East Timor, which meets the challenges of today's public higher education system.

\subsection{The performance evaluation as part of a new public management}

In the latter half of the nineteenth century already the UK and the US measured the performance of teachers in public schools (Pollit \& Bouckaert 2011). Woodrow Wilson believed in the need to create a system based on administrative efficiency criteria and Taylor advocated a generic approach to measuring the efficiency of workers (Pollit \& Bouckaert 2011, p.106). The interest in measuring the activity of the public sector has intensified, however, over the last quarter century (Bouckaert \& Halligan, 2008; Boyne et al, 2006) with the increasing pressure of contemporary societies on the state and particular on the general government sector to modernize its model and its management practices. The increasing sophistication of the needs of citizens and businesses that the public administration must meet, has raised the successive and continuous search for better efficiency rates, efficiency and quality of public services (Schachter, 2007). In addition to the economic performance indicators (Hood, 1996), also the quality of services has emerged as a priority (Coe, 2003). In many sectors the found-changing solution passed through privatization of services, other hybrid configurations have been adopted as public-private partnerships, while other areas remained strictly in the public sphere. The changes contemplated restructuring of organizational units to create more responsible and manageable entities, the use of outsourcing, the typical financial and accounting management of private companies, providing a better customer service and management personnel based on indicators performance. New public affairs management methods were thus adopted and designated new public management by resorting to the principles and procedures of private management (Hood, 1991; Osborne \& Gaebler, 1992).

The New Public Management (new public management) has been extensively implemented in countries such as Australia, Canada, Finland, the Netherlands, New Zealand, Sweden, the UK and the US (OECD, 2005, p. 95) and in this context, initiatives to improve the quality of public services led to the development of a wider field that is performance evaluation of the (as was signed in the Letter to UK Citizen, 1991, the Charter of the French civil service from 1993, in the Declaration of Quality of Service, 1994, and the Initiative of Quality of Service, 1995 in Canada (Pollit \& Bouckaert 2011, p.107).

It was therefore recognized the need to allocate qualified human resources to ensure efficiency levels and higher efficiency. Performance assessment came play a key role in the provision of basic information supporting decision-making in the management of human resources, particularly in terms of selection and career promotion (for example, determine if the salary increases and provide feedback between supervisors and assessors, and staff) (Coutts \& Schneider, 2004). However, as regards Mount (1984) "performance evaluation is one of the most problematic components of human resource management" (Mount, 1984, p.12).

The new management of human resources of public administration advocates the principles of decentralization, autonomy, accountability and flexibility (Perry, 2010), to introduce changes intended to get closer to citizens and therefore the provision of a service more effective, efficient, higher quality and lower waste (Carr \& Littman, 1990, Ka-ho, 2013). Osborne \& Gaebler (1992) pointed out the accountability of public officials, competition between services and the evaluation of results and performance indicators and performance of public service providers.

Performance evaluation was included, then various dimensions and has become more extensive. On the one hand, in addition to the management function, including the monitoring function, the performance evaluation has to intervene in decision making, in control and accountability (accountability). On the other hand, it became more extensive because its application has ceased to have only domestic reach, to pass also serve members of legislative bodies and even the public (Bouckaert, 1996, p. 234). The performance evaluation in public administration has become so over successive governments a "need for change" in the management of public affairs (Bouckaert \& Halligan, 2008).

No employee of the public sector was out of range of performance evaluation systems (Pollit \& Bouckaert, 2011). The pressure to meet targets or performance standards - such as the reduction of waiting lists of the hospital, better results in school exams, higher combat indices crime or best university research ratings introduced profound changes in public organizations: indicators performance factors have become increasingly associated with the allocation of resources and the allocation of financial rewards, which has come to transform organizational cultures and individual behaviors (Carter, 1998, p. 177). It analyze, therefore, to what extent the 
performance evaluation will achieve better standards of quality and efficiency of public service, and how the nature and organizational culture of the public service determine the evaluation process.

\subsection{The performance evaluation of civil servants in East Timor: Research problems}

East Timor established the Board of Workers' Performance Evaluation by Decree-Law No. 14/2008 of 7 May 2008. This document is an important tool in the introduction of a new culture of public administration, as it came permit assessment of the resources allocated to each of the public sector bodies and functions, and the creation of higher professional motivation conditions, permanent qualification and training of human resources. However, it was considered that the evaluation model implemented in 2008 did not allow an objective and systematic evaluation of the performance of civil servants, for which amendments were adopted in some of its articles, by Decree-Law No. 19/2011 of 8 of June. This new law allowing more objectivity criteria, introduced the annual frequency of evaluation and contemplated the completion of a set of forms with a view to achieving a comprehensive evaluation of employee performance, based on the service.

The performance evaluation of civil servants constitutes, as well as a systematic evaluation process in order to create a common understanding of the current state of the elements that are critical to achieving the goals and mission of public administration organization. It is a model that allows for objective indicators (metrics) regarding the performance of employees. This review is carried out with the participation of officials and managers (or leaders) for a holistic analysis of the organization, in order to be detected improvement opportunities identified and the necessary corrections. Corrections and improvements are then prioritized in a development plan of human resources, in which the feedback is the starting point for a new cycle of continuous improvement to the standards and objectives of the public service (Dessler, 2009). This guidance for continuous improvement of the public service is promoting a higher quality of services, since it ensures greater efficiency, effectiveness and economy of the public sector (Bouckaert \& Halligan, 2008).

Performance evaluation on Public Administration in East Timor was introduced in order to obtain objective indicators of performance of civil servants and thus outline the improvement actions aimed at continuous improvement of services. According to the words of Roger Carvalho (1998) treated a "continuous, systematic and structured process of analysis of the resources used and the results obtained that, bearing in mind the objectives set and using objective criteria, should contribute to the realization changes and / or the appropriate corrections, taking into account the detected shortcomings "(Carvalho, 1998, p. 191). Based on the process to guide, develop and encourage civil servants, performance evaluation promotes employee commitment to the organization and the service, the guidance for citizens and motivation in carrying out their functions, promoting productivity and efficiency administrative state organizations.

The performance evaluation process has thus to be considered as one of the central elements of human resource management, the effectiveness of which is assessed to the extent that it contributes to the achievement of organizational goals (Beaumont, 1993; Mouro, 2000). Hereinafter, performance management becomes a key tool for career management of human resources, the promotion of a culture of merit, development of employees and improving the quality of services provided to citizens, civil society, businesses and the community (Coutts \& Schneider, 2004).

One of the conditions for this process arises constructively to the civil servant and at the same time, promote a higher quality of service relates to the adequacy of procedures and performance evaluation criteria to the specific characteristics of public service it assesses. Now, in public higher education the teaching performance component is so specific that requires the evaluator of the procedures and evaluation criteria that meet the specifics of teaching in higher education institutions. To implement an effective performance evaluation system is necessary a compatible professional development culture and a culture of merit throughout the education system (Chism, 2004; Desimone, 2009; Knapper \& Cranton, 2001).

In alignment with the objectives of university education, thus become necessary procedural changes and performance evaluation tools that address the specifics of public higher education, capable of providing feedback and communication prone to continuous improvement. To achieve efficiency in the evaluation of teacher performance some authors argue, therefore, the adoption of procedures and specific evaluation criteria involving all stakeholders in the process, through well-defined roles to avoid duplication and to ensure the highest standards of performance and quality. The definition of roles is also important to define what is confidential and for how long, and the availability of time and the experience of assessing evaluated. These are factors that impact the efficiency of the evaluation process of teachers education institutions (Coutts \& Schneider, 2004). 
In the case of Timorese Public higher education, the means and the methods employed by the Public Administration to carry out the performance evaluation of its public officials fail to meet the specific and current challenges of public higher education. As these instruments are weak, it is necessary to implement methods to deal with the specificities proper to higher education and, therefore, objectively evaluate the productivity and effectiveness of teaching service in public universities.

It is in the face of this problem we raise the question (and which seek to launch contributions): What are the characteristics that must meet the performance evaluation system of higher public education teachers in East Timor?

We intend to points where principles, models and procedures must be based on the performance evaluation system of the Timorese university teachers. With this article we intend to demonstrate on the basis of scientific literature on the evaluation of performance in the various sectors of public administration, it is necessary to carry out an adaptation of criteria and evaluation methods of public higher education, in order to implement an assessment model that takes into account the specificities and the particular objectives of this public service.

After a period of political and social instability that followed the 1999 referendum and the Transitional Administration of the United Nations (UNTAET), East Timor lost much of its skilled workforce in all sectors, including education (Millo \& Barnett, 2004).

Despite the progress made (DRET, 2011), there are still indicators that concern the Timorese authorities and which require reform measures to change the overall picture of education, namely, the high rates of dropout and repetition rates, and which are appointed the following factors: the lack of textbooks and learning materials; the reduced number of hours of teaching; the low preparation of teachers; high ratios of students per teacher; the poor physical infrastructure; high number of students to contrast with the high rate of absenteeism of teachers; incomplete preparation of students for teaching language, Portuguese (Almeida, Martin \& Cabrita, 2014, p. 666).

Therefore, the Timorese authorities see reform of Education, through the training of national human resources, a key means to reduce inequalities, promote social and economic integration of populations, contribute to the eradication of poverty and achieve a better quality of life of the population, thus reaching those who are the country's Millennium Development Goals (DRET, 2009). The wider objectives of the current reform is to contribute to the socio-economic development and improving the capacity of human resources in the country (Berlie, 2007). Since the quality of teachers is a priority for the development of Timor-Leste ("Teachers are a priority," 2013) it is essential to the implementation of a new curriculum to ensure the formation of high-quality teachers (both scientific and pedagogical) (cit. in Albergaria Almeida, Martin \& Lopes, 2013), along with procedures and criteria that are in line with the country's educational goals.

In the specific case of Timorese public higher education, he was part of, in 2004, 17 higher education institutions in operation, serving more than 13,000 students. In early 2011, there were 11 institutions in operation, 9 of which possessed academic accreditation and served about 27,010 students. Since 2009, young female enrollment in higher education increased by 70\% (PED, 2011, p. 25). The National University East Timor (UNTL), established in 2000, is the only public university of East Timor exercising so a major role in terms of public higher education service and scientific and specialized research (PED, 2011 p. 26).

The Constitution of the Democratic Republic of East Timor (CRDTL, 2012) states that "The State shall guarantee the access of all citizens according to their abilities, to the highest levels of education" (CRD-TL, Part II, Section 59, p. 4). The state should then ensure the quality of education and the improvement of skills and competences of teachers, including university professors. It is in teacher training, productivity of their work and monitor their performance and their results lies the quality of educational institutions, in particular, and all Timorese education system in general.

As this time is being applied in East Timor too general and comprehensive assessment tool to all public administration bodies, we run the same risk does not measure what it proposes and therefore not contribute to the objectives that was set. Therefore urges to apply in East Timor a performance evaluation tool of public higher education teachers that meets the specifics that are proper of this education system.

As an UNTL teacher for several years, with institutional management responsibilities at the direction of one of the faculties, direct contact with the implemented assessment practices awakened to this issue, which will seek to address through theoretical and scientific review of different authors who have studied the evaluation of the theme of teacher performance and even those who have studied about public higher education. 

a new evaluation model

In East Timor, the evaluation of the performance of teachers, as part of an integrated assessment of the entire education system is seen as a key instrument for the promotion of quality of education, the success of student learning and of the responsible management and transparent education policies of all levels of education (paragraph 3 of article 42 of Law No. 14/2008 of 29 October). According to paragraph 1 of article 42 of Law No. $14 / 2008$ of 29 October, "the education system is subject in its efficiency, effectiveness and quality, permanent, continuous and public evaluation, which includes, in addition, in particular of student learning and teacher performance, non-teaching staff and educational establishments and teaching, the system itself as a whole and educational policy. "

According to the Law on Education (approved by Law No. 14/2008 of 29 October), higher education is oriented towards the development and improvement of the country. It's the same Basic Law which recognizes the need to undertake the evaluation and inspection of the education system at all levels of education (paragraph 2 of article 42 of Law No. 14/2008 of 29 October).

To ensure the quality of higher education, the Timorese government has implemented a system that aims to regulate all the qualifications of national institutions, through the National Qualifications Framework. The National Assessment and Academic Accreditation Agency is the body responsible for determining the standards and quality assurance criteria for all higher education courses. In addition, an administrative system able to coordinate all government interventions to higher education was implemented, the definition of priority budgets and the establishment of polytechnics for training in strategic industrial areas (PED, 2011, p. 26).

Therefore, the evaluation of teaching performance has taken in recent years, a role and a growing importance in terms of policies and educational practices while professional development mechanism of teachers and the importance of these to the goals of improving the learning of students (Nevo, 2005; Formosinho, Machado \& Formosinho, 2010). We know that teachers are the variable that, at school, more influences student performance (Goldrick, 2002) and in this sense, it is expected that teachers' performance evaluation is assumed as a strategy of "mobilization and motivation of teachers" (Moreira, 2009, p. 39).

Pacheco and Flores (1999) considers that this trend is the result of the overall purposes of school improvement, where concepts such as efficiency and efficacy, competitiveness and productivity of education have been dominant in the speeches of educational reform. Therefore, the evaluation was designed to work "in support of accountability processes and accountability related to educational outcomes" (Afonso, 1998, p. 116). The analysis of these purposes can observe that they merge into two main categories: accountability (associated with accountability) and the professional development of teachers. The accountability, the accountability for professional performance, reflected in the obligation to submit results to aid decisions related to career management. The professional development achieved by mobilizing the formative dimension of evaluation involves the analysis and reflection on teaching practices and their consequent improvement (Stronge, 2010; Tardif \& Faucher, 2010). These two purposes emerge in order to improve the school's performance inevitably associated with the quality of education (Bolívar, 2007) being this, in turn, associated with better learning for the students, mirrored in the improvement of their school results (Bolívar, 2007; Moreira, 2011). The realization of a "concerted effort to establish a logical link between the two purposes" (Stronge, 2010, p.27) has been a trend justified by the desire to evaluate the results and the processes that formed the basis of performance indicators, in an attempt to reconcile the willingness to improve teacher education and the continuous development of the teacher, this associated with monitoring the effectiveness of their performance and their career (Flores, 2009).

The debate on teacher performance assessment is justified by the consequences that may arise in terms of improving teaching practices and improve student learning. The inherent questioning process of teacher performance and reflection on how to make students learn more (Assael \& Pavez, 2008), induces the definition of strategic objectives so that, from professional development to be achieved better methods of work, ensuring the right to education to all students and thus the quality and equity of education (Murillo, 2007). This means that the importance of performance evaluation is anchored in their different purposes, which are underlying principles and education service mission (Day, 2010).

Several authors argue further that monitoring and evaluation should be prioritized in reform of the education sector situations (Day, 2007; Horton \& Mackay, 1999). According to Stufflebeam \& Shinkfield (2007), monitoring and evaluation are quality improvement processes, as others have pointed out their training and professional aspects of teachers (Scheerens, Glas \& Thomas, 2003; Stufflebeam, 2008). However, the definition 
of the principles is necessary, norms and values that underpin the implementation of an effective performance evaluation (Baratz-Snowden, 1991; Nyrenda, 1994).

According to Danielson (2010), the evaluation system requires three key components: "a coherent definition of the field of education (the 'what'), including decisions regarding the standard of acceptable performance, techniques and procedures for evaluating all aspects of education (the 'how'), trained evaluators who can make consistent judgments on performance, based on evidence of teaching practice, as manifest in the procedures. " De Ketele (2010), in turn, argues that the performance evaluation process should be guided by a recognition of posture, instead of a control position, as this results in more negative effects than positive effects on quality of education and the professional development of teachers. Through regulation and feedback, the evaluation should consider the expectations of teachers, together with the collection of indicators, to then communicate the goals of the institution. So Braskamp and Ory (1994) argue that evaluation should be based on communication that allows the taking of the institution's goals on the part of its employees, in this case the teachers. The same authors have recovered the metaphor "Sitting beside" to propose a performance evaluation definition that involves various actions such as commit, interact, share and trust, which involves working together discussing, reflecting, helping, building and collaborating. When two people sit "side by side" interested in evaluating the performance, can be very well evaluated and give feedback on the performance of another, but the context of this "exchange" is crucial - this context implies a dialogue to meet the perspective of each, before being made judgments (Braskamp and Ory, 1994). It is a communication approach between teacher and evaluator through reflection and discussion on performance standards and evaluation rules. The evaluation cycle should not end and need to keep teachers committed to the search for meaning in their own work and the continuous improvement of its performance, from the self-reflection and dialogue on the experiences developed (Aylett and Gregory, 1996).

The evaluation model of teaching the Timorese public higher education lacks a favorable communicative dimension to dialogue and define improvement plans. Performance evaluation should allow enhance teacher performance, through its continued development, in the certainty that this new approach will have a positive impact on the education received by the students. The personal and professional development of teachers are classified and identified jointly between evaluator and evaluated in order to promote the commitment and link between the teachers and the educational institution.

The final test of the reliability of the evaluation process is to show that it promotes the development of teaching staff and improvement of service. Effective assessment is one that allows thinking together the processes by which constitutes a personal and institutional development mechanism. The proper evaluation process should ultimately be subject to monitoring and a comprehensive impact assessment: monitoring will enable to assess whether the restructuring of education is being carried out as planned and the impact assessment will to establish whether the restructuring education is having the desired effect on teachers, students and the entire education system (Baker, 2000).

\subsection{Conclusion}

The performance evaluation process of teachers aims to improve professional performance, allowing obtain inputs that denote the quality of the institution. The aim of evaluating the performance of teachers make more oriented education for citizens, more efficient and higher quality (Pacheco \& Flores, 1999; Machado \& Formosinho, 2009). The causal relationship between the two assessment purposes - the responsibility for the accountability, and the professional development of teachers - based on a view that sees teachers a crucial resource for improving the education system, increasing the idea being that the quality of the educational process is clearly linked to the quality of teachers (Nevo, 2005; Machado \& Formosinho, 2009). Thus, it becomes clear that the evaluation of performance matters to improve the collective performance of teachers (Stronge, 2010), only because all the teachers can improve the quality of teaching practices. Therefore, the teacher performance evaluation is of utmost importance in the field of management of the quality of public education service, on the one hand, and the management of human resources management, on the other (Coutts \& Schneider, 2004).

Despite its long history (Pollit \& Bouckaert, 2011), the evaluation of teachers in higher education has always been a subject of controversy, because of the need to build consensus on the definition of the dimensions to be evaluated, the purpose of the evaluation, how to evaluate each dimension, who and when to assess and even how to use the evaluation results.

Considering the specificities and the current challenges of all Timorese education sector in general, and of public higher education, in particular, sought to demonstrate that the performance appraisal system in place in 
universities does not fit the object of evaluation, nor does the objectives of public higher education in the development of national human resources. Gathering input from authors also analyzed this issue, criteria were mentioned, practices and evaluation guidelines consider allowing the implementation of a "administrative evaluation system feasible, publicly credible, professionally acceptable, legally defensible and affordable" (Baratz-Snowden, 1991, p. 145).

Through a culture of excellence and quality present in educational institutions, the objective is to ensure that the public service education is increasingly efficient and effective in the public interest. For this reason, we believe that the implementation of a performance evaluation model that results fruitful and effective will require on the part of higher education institutions a priori existence of an organizational culture that values good performance and allows the recognition of merit. Specifically, it is set in the community of teachers continuous learning, mutual support and teamwork and guidance for public service.

Performance evaluation concludes, therefore, a strong debate in terms of processes, criteria, evaluators, effects and respective implications, which is far from being closed, mainly because they are needed more in-depth studies on the evaluation of performance and the specificities of institutions teaching that the evaluation is implemented (György, 2004). Studies on the performance evaluation of teachers in East Timor are even scarcer, due to the fact that it is a young independent state in hand with a larger project of national reconstruction. New and in-depth studies on the evaluation of teaching performance in East Timor will allow a wider debate on this issue and therefore, the development of measures conducive to change.

\section{References}

Altbach, P. G. (1998) Comparative Higher Education: Knowledge, The University and Development. Hong Kong, Comparative Education Research Centre, The University of Hong Kong.

Albergaria Almeida, P., Martinho, M. \& Cabrita, I. (2014). Evaluating The Impact Of Restructuring Secondary Education In East Timor. WCLTA. Procedia - Social and Behavioral Sciences, 141, pp. 665669.http://dx.doi.org/10.1016/j.sbspro.2014.05.116

Albergaria Almeida, P., Martinho, M. \& Lopes, B. (2013). Teacher Professional Development in the Context of International Cooperation: opportunities and challenges. In Y. Bashevis \& Y. Weidenseld (Eds.). Professional Development: Perspectives, Strategies and Practices (pp. 147-164). New York: Nova Publishers.

Assaél, J., \& Pavez, J. (2008). La construcción e implementación del Sistema de Evaluatión del Desempe-o Docente Chileno. Revista Iberoamericana de Evaluatión Educativa, 1, 2, pp.41-55.

Baker, J. (2000). Evaluating the Impact of Development Projects on Poverty - A Handbook for Practitioners. World Bank: Washington D. C. http://dx.doi.org/10.1596/0-8213-4697-0

Baratz-Snowden J. (1991). Performance assessments for identifying excellent teachers: The National Board for Professional Teaching Standards charts its research and development course. Journal of Personnel Evaluation in Education 5, 2, pp. 133-145. http://dx.doi.org/10.1007/BF00117334

Beaumont, P.B. (1993). Human Resource management: Key concepts and skills. London: Sage Publication.

Berlie, Jean A. (2007). Schooling inTimor Leste, in Postiglione, Gerard A. and Tan, Janson (Ed.) Going to School in East Asia. Westport, Connecticut and London: Greenwood Press, pp.401-412.

Bouckaert, G. (1996). Measurement of Public Sector Performance: Some European Perspectives, in A. Halachmi and G. Bouckaert (eds.) Organisational Performance and Measurement in the Public Sector, pp. 223-37. London, Quorum Books.

Bouckaert, G. \& Halligan, J. (2008). Managing Performance: International Comparisons. London, Routledge/ Taylor and Francis.

Boyne, G. A., Kenneth J. M., O'Toole Jr., L. J. \& Walker, R. M. (Ed.) (2006). Public Service Performance: Perspectives on Measurement and Management. Cambridge, Cambridge University Press. http://dx.doi.org/10.1017/cbo9780511488511

Braskamp, L.A. \& Ory, J.C. (1994). Assessing faculty work: Enhancing individual and institutional performance. San Francisco: Jossey-Bass Publishers.

Bolívar, A. (2007). Um olhar actual sobre a mudança educativa: onde situar os esforços da melhoria? In C. Leite, A. Lopes (Eds.), Escola, currículo e formação de identidades: Estudos de investigação (pp. 13-50). Porto: Edições Asa.

Carr, D. \& Littman, I. (1990). Excellence in Government: Total Quality Management in the 1990s. Arlington, VA: Coopers and Lybrand.

Carter, N. (1998) 'On the Performance of Performance Indicators', pp. 177-94, In M-C. Kesler, P. Lascoumbes, M. Setbon, and J.-C. Thoenig (Ed.) E'valuation des politiques publiques. Paris, L'Harmattan. 
Carvalho, Rogério (1998). Avaliação de serviço público: a avaliação na administração pública. In Encontro INA, Lisboa, 1998 - A avaliação na administração pública: acta geral do 1o Encontro INA. Oeiras.

Coutts, L. M. \& Schneider, F. W. (2004). Police officer performance appraisal systems: How good are they?, in Policing: An International Journal of Police Strategies \& Management, 27, 1, pp.67-81. http://dx.doi.org/10.1108/13639510410519921

Coe, C. (2003). A Report Card on Report Cards. Public Performance Management Review, 27, 2, pp.53-76.

Chism, N. V. N. (2004). Characteristics of effective teaching in higher education: Between definitional despair and certainty. Journal of Excellence in College Teaching, 15, 3, pp. 5-36.

Danielson, C. (2010). Melhorar a prática profissional. Um quadro de referência para a docência. Lisboa: Ministério da Educação.

Day, C. (2010). Formas de avaliação docente em Inglaterra: Profissionalismo e Performatividade. In M. Flores (Ed.), A avaliação de professores numa perspectiva internacional: Sentidos e implicações (pp. 141-161). Porto: Areal Editores.

Day, C. (2007). A reforma da escola: Profissionalismo e identidade dos professores. In Maria Assunção Flores \& Isabel Carvalho Viana (Orgs.), Profissionalismo docente em transição: As identidades dos professoresem tempos de mudança (pp. 109-129). Braga: Universidade do Minho (CIED).

De Ketele, J. (2010). A avaliação do desenvolvimento profissional dos professores: Postura de controlo ou postura de reconhecimento? In M. Alves, E. Machado (Eds.), O pólo de excelência - Caminhos para a avaliação do desempenho docente (pp. 13-30). Porto: Areal Editores.

Desimone, L. M. (2009). Improving impact studies of teachers' professional development: Toward better conceptualizations and measures. Educational Researcher, 38(3), pp. 181-199. http://dx.doi.org/10.3102/0013189X08331140

Dessler, Gary (2009). Human Resource Management. Prentice Hall, Fifth Edition.

Flores, M. (Eds.) (2010). A avaliação de professores numa perspectiva internacional: Sentidos e Implicações. Porto: Areal Editores.

Flores, M. (2009). Da avaliação de professores: Reflexões sobre o caso português. Revista Iberoamericana de Evaluación Educativa, 2, 1, pp. 239-256.

Formosinho, J., Machado, J., \& Formosinho, J. (Eds.) (2010). Formação, desempenho e avaliação de professores. Mangualde: Edições Pedagogo.

Goldrick, L. (2002). Improving Teacher Evaluation to Improve Teaching Quality. National Governors Association.

György, H. (2004). The spirit of management reforms: towards building an explanatory model of NPM. A comparative case study of Queensland and Hungarian administrative culture. Public Management Review, 7, 4, pp. 495-513.

Hood, C. (1991). A Public Management for all Seasons. Public Administration, 69, 1, Spring, pp. 3-19. http://dx.doi.org/10.1111/j.1467-9299.1991.tb00779.x

Hood, C. (1996). Exploring Variations in Public Management Reform of the 1980s' (pp. 268-317). In H. Bekke, J. Perry, and T. Toonen (Ed.) Civil Service Systems in Comparative Perspective. Bloomington and Indianapolis, Indiana University Press.

Horton, D. \& MacKay, R. (1999). Evaluation in developing countries: an introduction. Knowledge, Technology \& Policy, 11, pp. 5-12. http://dx.doi.org/10.1007/s12130-999-1001-9

Ka-ho, M. (2003). Similar Trends, Diverse Agendas: Higher education reforms in East Asia. Globalisation, Societies and Education, 1:2, pp. 201-221. http://dx.doi.org/10.1080/14767720303910

Knapper, C \& Cranton, P. (Ed.) (2001). Fresh approaches to the evaluation of teaching. New Directions for Teaching and Learning, 88. http://dx.doi.org/10.1002/tl.32

Millo, J. \& Barnett (2004). Educational development in East Timor. International Journal of Educational Development 24, pp. 721-737. http://dx.doi.org/10.1016/j.ijedudev.2004.04.005

Moreira, M. (2011). 0 lugar da observação na avaliação docente: 0 que vale o que observamos? In M. Alves, M. Flores, E. Machado (Eds.), Quanto vale o que fazemos? Práticas de avaliação de desempenho (pp. 17-38). Santo Tirso: De Facto Editores.

Moreira, M. (2009). Supervisão interpares, avaliação e autonomia profissional. ELO, 16, 37-41. A avaliação de desempenho docente na perspectiva dos directores escolares: um estudo empírico 189.

Mount, M. (1984). Satisfaction with a Performance Appraisal Systsem and Appraisal Discussion. Journal of Occupational Behaviour 5, 4, pp. 271-279. http://dx.doi.org/10.1002/job.4030050404

Mouro, E. (2000). Gestão dos recursos humanos- influenciam e determinantes do desempenho. Lisboa: Edições Sílabo.

Murillo, J. (2007). Uma visão panorâmica da avaliação de desempenho docente na Europa e na América. In C. Ramos (Ed.), Avaliação de professores: Visões e realidades. Actas da Conferência Internacional (pp. 33-42), Lisboa: Conselho Científico para a Avaliação de Professores.

Nevo, D. (2005). The conceptualization of educacional evaluation: an analytical review of the literature. In E. House (Ed.), New Directions in educational evaluation (pp. 15-29). Oxon: Routledger Falmer. 
Nyrenda, S. (1994). Assessing Highly Accomplished Teaching: Developing a Metaevaluation Criteria Framework for Performance-Assessment Systems for National Certification of Teachers. Journal of Personnel Evaluation in Education 8: pp. 313-327 Kalamazoo, The Evaluation Center, Western Michigan University. http://dx.doi.org/10.1007/BF00973727

OCDE (2005). Modernising Government: The Way Forward. Paris, OECD.

Osborne, D. and Gaebler, T. (1992) Reinventing Government (Addison Wesley, Reading MA).

Pacheco, J. A., \& Flores, M. A. (1999). Formação e avaliação de professores. Porto: Porto Editora.

Perry, J. L (2010). A Strategic Agenda for Public Human Resource Management Research. Review of Public Personnel Administration, 30 (Edição original, 16 novembro de 2009). http://dx.doi.org/10.1177/0734371X09351821

Pollit, C \& Bouckaert, G. (2011) Public Management Reform. A Comparative Analysis - New Public Management, Governance, and the Neo-Weberian State, 3a ed. Nova Iorque, Oxford University Press Inc.

Scheerens, J., Glas, C. \& Tomas, S. M. (2003). Monitoring and evaluation (M \& E) in education: concepts, functions and context. Educational Evaluation, Assessment and Monitoring, 1, pp. 3-16.

Stronge, J. (2010). 0 que funciona, de facto, na avaliação dos professores: breves considerações. In M. Flores (Ed.), A avaliação de professores numa perspectiva internacional: Sentidos e implicações (pp. 22-43). Porto: Areal Editores.

Stufflebeam, D. L. (2008). Egon Guba's conceptual journay to constructivist evaluation: a tribute. Qualitative Inquiry, 14, pp. 1386-1400. http://dx.doi.org/10.1177/1077800408325308

Stufflebeam, D. L. \& Shinkfield, A. J. (2007). Evaluation theory, models and applications. São Francisco, JosseyBass.

Tardif, L., \& Faucher, C. (2010). Um conjunto de balizas para avaliação da profissionalização dos professores. In M. Alves, E. Machado (Eds.), 0 pólo da excelência: Caminhos para a avaliação do desempenho docente (pp. 32-53). Porto: Areal Editores.

\section{Documentos normativos}

CRD-TL (2012). Constituição da República Democrática de Timor Leste. Publicação Oficial da República Democrática de Timor Leste, 20 de Maio de 2012.

Lei n. 14/2008, de 29 de Outubro. Aprova a Lei de Bases da Educação de Timor Leste. Publicação Oficial da República Democrática de Timor Leste, Série 1, № 40.

Decreto-Lei N. 14/2008, de 7 de Maio. Regime da Avaliação do Desempenho dos Trabalhadores da Administração Pública. Publicação Oficial da República Democrática de Timor Leste, Série

Decreto-Lei no 19/2011, de 8 de Junho. Aprova a Segunda Alteração ao Decreto-Lei N.o 14/2008, de 7 de Maio (Regime da Avaliação do Desempenho dos Trabalhadores da Administração Pública). Publicação Oficial da República Democrática de Timor Leste, Série 1, № 21.

PED (2011). Timor Leste. Plano Estratégico de Desenvolvimento 2011-2030. Dili, República Democrática de Timor Leste.

DRET (Democratic Republic of East Timor) (2009). The Millenium Development Goals, Timor-Leste. TimorLeste National Report.

DRET (Democratic Republic of East Timor) (2011). Timor-Leste National Strategic Development Plan 2011 2030. Dili, East Timor. 